\title{
The Impacts of 'Problem-Based Learning' Approach in Enhancing Critical Thinking Skills to Teaching Literature
}

\author{
Mairas Abd Rahman (Corresponding author) \\ English Language Department, Faculty of Languages and Communication, \\ Sultan Zainal Abidin University,Gong Badak Campus,21300, Kuala Terengganu, Terengganu, Malaysia \\ E-mail: mairas@unisza.edu.my \\ Mohd Nazri Latiff Azmi \\ English Language Department, Faculty of Languages and Communication, \\ Sultan Zainal Abidin University,Gong Badak Campus,21300, Kuala Terengganu, Terengganu, Malaysia \\ E-mail: mohdnazri@unisza.edu.my \\ Zanirah binti Wahab \\ English Language Department, Faculty of Languages and Communication, \\ Sultan Zainal Abidin University,Gong Badak Campus,21300, Kuala Terengganu, Terengganu, Malaysia \\ E-mail: zanirah@unisza.edu.my \\ Ahmad Taufik Hidayah bin Abdullah \\ English Language Department, Faculty of Languages and Communication, \\ Sultan Zainal Abidin University,Gong Badak Campus,21300, Kuala Terengganu, Terengganu, Malaysia \\ E-mail: taufikhidayah@unisza.edu.my \\ Nor Jijidiana binti Azmi \\ Modern Languages and Communication Department, Faculty of Languages and Communication, \\ Sultan Zainal Abidin University,Gong Badak Campus,21300, Kuala Terengganu, Terengganu, Malaysia \\ E-mail: jijidianaazmi@unisza.edu.my
}

Received: 25-06-2016

Accepted: 29-08-2016

Advance Access Published: September 2016

Published: 01-11-2016

doi:10.7575/aiac.ijalel.v.5n.6p.249

URL: http://dx.doi.org/10.7575/aiac.ijalel.v.5n.6p.249

The research is financed by Universiti Sultan Zainal Abidin Research Grant. No UniSZA/2015/DPU/15.

\begin{abstract}
Teaching can be challenging task especially when the students are categorized as reluctant readers, low self-motivated and lack of critical thinking skills. Therefore, this study focuses on a successful problem-based learning approach on university course called 'Literature for Language Purposes' taken by Bachelor of English with Communication students at a local Malaysian university. The aim of this study is to investigate the impacts of carrying out problem-based learning in teaching literature. The project involved 55 undergraduates and part of their major course assignments was to organize and participate in an annual English language drama competition. The data was collected through students' reflective journals, researchers' reflective journals, response from end of semester questionnaire given and, lecturers' evaluation on FILA tables. The findings show that problem-based learning is suitable and beneficial in teaching and enhancing critical thinking skills.
\end{abstract}

Keywords: Problem-based learning, literature, drama, critical thinking

\section{Introduction}

Many years ago, it was common for educators to transfer the knowledge since teaching and learning process would revolve around teacher centered philosophies such as essentialism and perennialism (Sadker, Sadker \& Zittleman, 2008). However, early 19s and 20s have witnessed that philosophy of education has gone through changes from teachercentered to student-centered philosophies. World nowadays is in need of students who can be creative future workers to serve the workforce. Studies have recommended that students can no longer be "passive recipients of given information" and called for changes in pedagogical and learning environments that are geared towards "developing thinking skills and harnessing creativity" (Yip, 1997, 391). The obvious criteria these student-centered approaches have are in terms of working together towards learning goal and reforming better society in this world. There is an urgency need for these students to be exposed with student centered approach as a preparation for future challenges. Other 
concerns included students' lack of critical thinking skills in class and beyond, and courses being too focused on content, the latter easily causing boredom among students and 'burnt-outs' in them as well as teachers (Tan, 2003).

Over the past few decades, there has been increasing pressure on higher education worldwide to re-examine and make explicit its aim and outcomes (Savin-Baden, 2000). The moves towards a model of higher education that is responsive to market demands and forces in the wider society has increased the demands for graduates who are capable to do work collaboratively with colleagues, competitive, creative, strong in a sense of determination, never give up other than honest and sincerity in executing and completing the task. Furthermore, students from Generation $\mathrm{Y}$ are more demanding compared to students in the olden days. They are confident, ambitious, appear to have both a greater maturity ('street wise', global awareness) and a lesser maturity ('me' focus, poor self-awareness and emotional intelligence) and often seek to form working groups on their own terms, rather than accept what has been given (Honore \& Schofield, 2009). Given a chance, these students can be good a workforce who possess the characteristic of creative thinkers who possess critical thinking skill. According to Saeed \& Rousta in 2013, acquiring thinking skills has been increasingly emphasized in education, especially with forces in globalization demanding its workers to be adaptable over and above being productive. Critical thinking is also considered as the central to higher levels of education or a fundamental goal of learning (Kuhn, 1999; Keeley \& Shemberg, 1995).

According to Honore and Schofield (2009), the current education system is largely failing this generation in terms of preparation for the workforce, especially concerning communication and numerical skills, approaches to learning, creativity, working with others and rewards and development. Therefore, by looking at the latest characteristics of students nowadays, a paradigm shift in our education system especially in the teaching approach which is more challenging is required to facilitate the needs of the students and society in general. Higher education needs to develop a role beyond that of creating and transmitting knowledge, by enhancing the knowledge creation capacity of individual and professional communities. It is a skill that would create our students to become innovative and effective in the modern workplace (Saeed \& Rousta, 2013). By providing challenges and instructional strategy which are appropriate for Generation Y, it is hoped the students will be able to improve their critical thinking skills as well as to adapt with situation awaiting them in the future.

\subsection{Critical Thinking Skills in Literature Classroom}

Teaching literature is not as easy as we thought in this challenging era. Teaching literature for ESL students might be a challenging task if the teaching technique is outdated or predictable (Siti Norliana, 2008). The need to try new approaches to teaching language in Malaysia has become increasingly urgent since the general complaint published almost every day in the media regarding the English language for the last few decades points to the deterioration of proficiency especially among youths, despite the years they toiled learning the language at school (Normala \& Mohamed, 2013). In addition, the changes in society also imply that the statistic acquisition of facts cannot adequately prepare students for the world beyond school environment (Saeed \& Rousta, 2013). In order to make sure the students will maintain their interests and motivations towards learning literature subject, changes need to be done. There are many instructional approaches that educators could adopt in the classroom. Moreover, in order to do this change, the students need to be able to think "critically and creatively at the highest possible level" (Fisher, 2001, 8).

The students sometimes have bad impression towards literature subject. Part of it is because they have to finish reading literary works first before they can critically discuss about them. When it comes to reading and interpreting the literary works, it is not about passive reading. This is due to reason that most of the literary works in literature use archaic words and not to mention are lofty in terms of style and language used. These undeniable characteristics of literature will give problem to incompetence students in the class. In literature, interactive model of reading process is an approach that takes into consideration the readers as well as the literary works they are interpreting. It is also well known that meaning is created through reader's interaction with a text; therefore meaning is created partly by what is supplied by a work and partly by what is supplied by the readers (Kirszner \& Mandell, 2007, p. 9). Due to these reasons, there is an urgent need for these students to be critical thinkers in literature class. It will be possible for the students to tease out the issues discussed from the literary works in the classroom if they are critical thinkers.

Eventhough the students nowadays are known as Generation Y, it seems that they are not given a proper challenge which suit their ability. According to a research in Pakistani universities and colleges, there is hardly any research and effort to apply cognitive teaching strategies and techniques to teach literature in order to develop students' thinking and other cognitive processes such as perception, memory, retrieval and transference (Hussain, Nafees and Jumani, 2009). These students are not given the right trigger to work with. In fact, the teaching approach will fall back to didactic lecture which is inherited from student-centered approach. In addition, the teachers must adhere very closely to the standardized syllabus administered by the Ministry of Education (Normala \& Mohamed, 2013). The most important matter would be to finish the syllabus within 14 weeks. Due to the reason, priority for the lecturers would be to complete the syllabus and there will be not much done towards the development of critical thinking skills in the students. From researchers' observation after teaching literature for a year and a half, the students seemed to be very happy if they were given complete notes at the end of the class. They preferred to be told in details about each topic rather than working together collaboratively to decide, filter and depict the information that is useful for the process of learning how to learn to happen. These clearly show that the students are still in passive mode, still in their comfort zone as they are not challenged and have not yet transferred themselves to a new pace of active learning. In 1986, Meyers says that the full process of critical thinking 'is not a dispassionate learning process in which students need only to be shown new ways of perceiving things in order to follow it, but a threatening encounter that challenges one's very 
selfhood' (p.96). Improvement and modification in teaching methods for lecturers as well as learning skills among the students should be done as to produce future workers who have critical thinking skills within them.

The rapidly changing present world demands people to be multi-tasked, equipped with the skills of collaboration and flexibility, and have the ability to process information (Hussain et al., 2009). At present, higher institutions around the world are raving and competing to produce future employees who are independent, creative, dare to be challenged, active and know how to do their work well eventhough little instructions are given. Future employees are expected to know as well as to implement critical thinking skills in life. For Jeffrey and Woods (2003, p. 122), education needs to foster creativity that is to encourage flexibility, innovation and "positive identities." However, this dream will only be a fairy tale that will never come true if we do not initiate any action on how to overcome the problems using the right instructional approach in the classroom. In producing generation of university students who are called critical thinkers, changes have to be taken in faculty level with sincere intention to improve the quality of undergraduate students in higher institutions. According to Coles and Robinson in 1991, "The problem now is not whether we can teach thinking. The evidence suggests we can. The problem continues to be whether we are willing to make the pedagogical changes necessary to do so, and if we are, which changes might be the most effective." In 1997, Barnett emphasized the need to enable learners to shift towards the more active challenging mode. The lesson can be changed into active mode with the help of lecturers with the willingness to do positive modification by using correct approach which could trigger critical thinking skills among the students.

Accepting critical thinking as an educational ideal brings with it ramifications for what we teach and how we teach (Weissinger, 2003). Early resistance will happen on the students' sides since this approach is still new for them. According to Kinney (1980), there is talk of manner in which students "stubbornly resist" critical thinking. This research is carried further by Keeley and Shemberg (1995) by linking the resistance to critical thinking to situations in psychotherapy. As the result, both of the researchers do acknowledge 'that students are often unresponsive because critical thinking involves new, and complex activities, and, in particular, "because they are afraid". Traditional programmes of education and training usually put tremendous emphasis on content (Tan, 2003). The students are used to be spoon-fed due to traditional methods of teaching literature. The purpose of traditional method is for the students to accumulate the transferred information and reproduce the content in final examination at university level. As a result, though students successfully get a degree at the end of the courses, they remain unable to process and manipulate information, synthesize and evaluate ideas, make connection between classroom learning and practical world outside, or generate personal and innovative ideas (Hussain et al., 2009). In 1997, McKay and Kember conducted a study on the 'spoon feeding' of students by unchallenging 'transmission mode of didactic learning. The researcher interviewed the students pertaining to the programme that had been didactic and later modified the course to facilitate active learning. The result is positive and the students adopted a deep approach learning to their learning. The students also mentioned that when they were actively challenged to think critically, they liked it.

Therefore, critical thinking which involves knowledge of strategies as well as a propensity toward applying them, is a major component of higher education and a national priority if we were to produce future employees who are competitive, can work collaboratively with colleagues, know how to work on the task given as soon as they were given the instruction, very creative with many alternatives in completing the tasks given, strong in a sense of determination and never give up other than honest and sincerity in executing and completing the task (Brookfield, 1987). Problem solving, goal setting, and creative thinking are considered specific skills required for the twenty first century workforce (Hussain et al., 2009). Action has to be taken as to make sure that it is not too late to mold undergraduate students to be creative critical thinkers.

\subsection{Problem Based Learning as a Sound Instructional Strategy to Enhance Critical Thinking}

Few years back, good practice of teaching was about making content knowledge "visible" to students (Tan, 2004). Good pedagogy is about transferring knowledge to the students by giving didactic lectures and notes. On the students' takes, they will receive, memorize and recall the information for examination purpose. In industrial age, this is considered as enough for the classroom. Towards last decade of the $20^{\text {th }}$ century, good pedagogy was about making teachers' thinking visible for the students to model from. In other words, effective teaching was characterized by modeling the process of learning so that students could observe and learn process, problem solving, and thinking skills while acquiring content knowledge

Educators have to use new ways of looking at knowledge and participation in the learning process. Pedagogy in the $21^{\text {st }}$ century has to go beyond making content visible and making teacher' thinking visible to the students for the purpose of modelling and scaffolding (Tan, 2004). The challenge of education in $21^{\text {st }}$ century is to design learning environments and processes where students' ways of thinking and knowing are manifested in active, collaborative, self-regulated, and self-directed learning. The role of educator is to enable students to recognize various dimensions of their thinking and to sharpen their abilities to deal with real-world problems. With PBL, students are offered opportunities, to explore a wide range of information, to link the learning with their own needs as learners and to develop independence in enquiry (Savin-Baden, 2000). The skills which the students learn from PBL approach will finally mold them to be selfindependent and critical thinkers in the future.

In PBL environment, students regularly engage in metacognition. When discussing a PBL problem, students think aloud, sharing their thoughts via description and/or visual representation. Other students in the group question for clarification or check for accuracy (Davidson \& Worsham, 1992; Weissinger, 2003). At the same time, those listening should be thinking, "What am I hearing that supports what I thought before?" These exchanges trigger the process of 
metacognition. The goal is to enable students to become reflective critical thinkers who demonstrate a consistent intrinsic motivation to be aware, inquisitive, organized, analytical, confident, tolerant, judicious when weighing alternatives, and intellectually honest when judging whether to accept others' ideas and philosophies as truth or when challenged by circumstances (Facione et al., 1997; Hunkins, 1989; McCombs \& Whisler, 1997). Their attitudes also should shift toward openness and a tolerance for diversity (Pascarella \& Terenzini, 1991). Ultimately, transformative change occurs when people are willing to examine and challenge their own thinking (Senge, 1990).

The objective of teaching literature in the classroom is to improve students' critical thinking skills and one out of many instructional strategies that is effective for achieving this objective is by using problem-based learning (PBL). Problembased learning (PBL) process essentially consists of the following stages: (1) meeting the problem; (2) problem analysis and generation of learning issues; (3) discovery and reporting; (4) solution presentation and reflection; and (5) overview, integration, and evaluation, with self-directed learning bridging one stage and the next (Tan, 2003). All the steps in this approach will force the students to collaborate in their respective groups and they have to hold discussions and negotiations to achieve consensus for solutions to postholes given. The process of moving towards the solution presentation and reflection are very important in teaching these students to learn how to learn.

PBL is an excellent environment within which to develop critical thinking skills because it provides opportunities to grow in all four components of critical thinking: (1) PBL can provide a strong grasp of knowledge base-factual and applied; (2) it provides opportunities for the development of critical appraisal skills; (3) its environment encourages students to question; and (4) in PBL faculty step back and allow students to direct their own learning, which becomes the foundation for future professional behaviors (Weissinger, 2003). These steps are compulsory in preparing the students for future workforce who are creative, can bear challenges other than being critical thinkers. Problem-based learning gives hands-on experience for students to learn with complexity, to realize that there are no straightforward and easy answers to problem scenarios, but learning and life takes place in contexts, which affect the kinds of solutions that will be taken at the end of the day. Learning such as this is not just a straightforward method of solving problems, but it helps people to learn how to learn and to link learning with their own interests and motivations (Savin-Baden, 2000).

The nature of problem-based learning is the students have to work collaboratively in achieving the objectives of the group. These students are presented open-ended, messy and ill-structured problems that they work together to form a better understanding through the listing of known facts, generation of possible solutions, identification of issues that need further research, and eventual proposal of a resolution with rationale (Weissinger, 2003). Collaboration is a key component of PBL learning environments. Yet, specific structures must be in place (e.g., positive interdependence, individual accountability) for students' to work together productively (Brush \& Saye, 2001). Since it is done in a group, there will be cognitive dissonance happening among group members. According to Meyers (1986), this situation is hallenging by the creation of 'disequilibrium' which means 'Teaching critical thinking involves intentionally creating an atmosphere of disequilibrium, so that students can change, rework or reconstruct their thinking'. In the process, the students have to undergo self-directed learning before discussion session with their group members in the next meeting. They will present the information from self-directed learning and defend their frame works so that it will be the chosen solution in the meeting. This will teach them on how to learn through modelling, patient, accept others opinion and collaborate in group. Students are encouraged to activate their prior knowledge; perform in a context that resembles the " real world" where the problem will be applied; and better understand, process, elaborate, and recall information (Bridges \& Hallinger, 1998). PBL “mirrors [adult learning theorist Malcomb] Knowles's context for supporting lifelong learning, particularly address[ing] self -directed learning; accessing up-to-date information resources efficiently and habitually; and interaction between learners for critical reflection through multiple perspectives (Maudsley \& Strivens, $2000,524)$. With the reasons mentioned above, the researchers would like to investigate the impacts of carrying out PBL in teaching literature with sincere attempt so that the students will finally enjoy the learning session, appreciate literature and be critical thinkers.

\subsection{Research Question}

The research questions are:

1. What are students' perceptions towards studying Literature by using PBL approach as the instructional approach in the class?

2. What are the impacts of 'Problem-Based Learning' Approach in Enhancing Critical Thinking Skills to Teaching Literature?

\section{Method}

\subsection{Participants}

This research applies a qualitative approach. The research involved 55 (13 male and 42 female) students from semester three who participated in literature classroom for the subject of "Literature for Language Purposes". Patton states that there are standards used in choosing participants and site and it is because they are "information rich" (1990, as cited in Creswell, 2007). The students were divided into two groups (Group A with 27 students, group B with 28 students). They were from mixed-ability group and their English language competency ranged from average to high proficiency level. The course is a compulsory course for year two students.

\subsection{Data Collection}

Researchers kept a journal, an introspective record of teaching experience. The researchers chronicled the research 
methodology as in the cycle of implementation, evaluation, reflection and change. Researchers wrote entries in the journal on a regular basis that consisted of personal experience, theoretical field, instructional strategy, and methodological notes. The researchers recorded all decisions made about the research study and the actions taken in the context of the research study. As for the students, they were required to have a reflective journal for the semester. The reflective journals were collected at the end of the semester together with all of the required documents to support the study.

Closed and open-ended survey questionnaire were used to elicit the data. About 20 minutes was allotted to the administration and answering of the survey questionnaire. Respondents were allowed to work on their own pace, and seek clarification when required. They were also reminded that the survey questionnaire was not a test; therefore there was no right or wrong answer to any question.

FILA tables and reflection forms were evaluated by the researchers. About 40 minutes was allotted to the administration and answering of the reflection forms. Respondents were allowed to work at their own pace, and seek clarification when required. They were also reminded that the reflection forms were not a test; therefore there was no right or wrong answer to any question.

\subsection{Procedures}

The problem-based approach was introduced and implemented for four months to supplement teaching and learning for the course. The students were first exposed and introduced to the approach in the first week of the semester. The data from researchers and students' reflective journals were analyzed and classified by types of responses given. The researchers began to compare and contrast 55 profiles by clustering the responses from all the journals. The information from reflective journals was then quantified and tabulated for qualitative interpretation. As for researchers' reflective journals, they were read to develop ideas about categories and relationship relevant to the research questions.

For the lecturers' evaluation on FILA tables and presentation of drama conference, the students were exposed to FILA table and five ladders of active learning. The students were separated into group one and two for $3 \mathrm{~A}$ and three and four for $3 \mathrm{~B}$. For group one and three, it consisted of ten female and three male students for $3 \mathrm{~A}$ and 11 female and three male students for 3B. The groups produced drama with genre of comedy. As for group two, there were ten female and four male students while group four had 11 female and three male students. Each of the groups was given a task to produce drama that revolved around tragedy. The students had to use all the elements of drama they learnt in the classroom ad later tailored it with themes that were more than two in it. In the process, the students had to work collaboratively with their group members. There were three drama conferences were held before the final performance was executed. Three lecturers from Literature field were invited during the conferences as to evaluate pre and while drafts of the frameworks for drama. During these sessions, there were question and answer sessions between students-students as well as students-lecturers. This was also the stage of where we could see that critical thinking happened. In the last conference, the students would have to present their finalized version of the drama to be approved by the lecturers before they could execute the performance in front of the audience. Drama performance was carried out in December $11^{\text {th }}, 2012$, at the end of semester.

The final step was to analyze, organize and transform the end semester survey questionnaire into numbers. The information then was quantified and displayed in tables for qualitative interpretation by using discourse analysis approach (Rashid, Rahman, \& Rahman, 2016). The objective is to investigate the finalized impacts from 55 students after using PBL in literature classroom for four months.

\section{Results}

\subsection{Students' Perception towards Studying Literature by using PBL approach as the instructional approach in the class}

To answer the question, the researchers elicit the data from the survey questionnaire. At the end of the semester, the survey questionnaire was conducted to 55 students who had gone through the intervention. The students would have to answer three out of eight questions forwarded to them. In order to elicit data from the first question, three alternatives were given for the students to choose. Based on the first question: "How do you feel about PBL approach that has been introduced to your literature class for the whole semester?", five students chose "Fair", 50 students chose "Good" for their choice and none of the students had chosen "Poor" for their choice. It could be said that the majority of students (50 students) felt good about using PBL approach in literature classroom and five more students were in between about their feelings regarding using the same approach in the classroom.

As for Question Two: "How useful is the process in PBL approach in helping you make changes towards the way you learn now and in the future?", two students had chosen "Fair" for their choice and 53 students chose "Good" for their answer to the question and none of the students had chosen "Poor" for their choice. For the question, the majority of the students (53 out of 55 students) believed that process in PBL approach help them to make changes towards the way they learn now and in the future.

As for Question Three: "How would you rate PBL approach that had been implemented in your literature class", out of 55 students, two students had chosen "Fair" for the answer, 53 students had chosen "Good" as their best choice while none of the students chose "Poor" for their answer. It can be concluded that the majority of the students (53 out of 55 students) believed that PBL approach is appropriate to be applied in Literature classroom.

From Students’ Reflective Journal 
The reflective journals were collected at the end of the semester together with all of the required documents to support the study. For the first question in the reflective journal, in their first exposure towards class, all of the students wrote that they had a feeling of apprehension regarding the approach when they first heard about it. This is because they lacked knowledge and exposure to what PBL approach is and how to use them. As the semester went on, the students seemed to like the activities in the literature classroom. Two of the students mentioned in the journals that:

Excerpt1

"I know nothing about PBL..for me it is just the same, you divide work between friends, the lecturer will ask the students to do this and that...settle it, then compiled to be submitted to lecturer..but PBL is not like that..it is about sharing responsibility...everybody should know their parts..we work towards the same objective...combination of PBL and literature is awesome!!."

(October $\left.12^{\text {th }}, 2012\right)$

Excerpt2

\begin{abstract}
"I found that PBL in the class is quite interesting..no more we can relax with our facebook and $i$ Pad at the back..we have to give our part as to make the learning gives meaning to us...this is truly for Gen Y like us...full lectures doesn't require us to think, just waiting for notes, but this one is different..we crack our head.. and we got positive skills out of it.
\end{abstract}

(September 28 $\left.{ }^{\text {th }}, 2012\right)$

51 out of 55 students loved to use PBL approach in the classroom and they also had positive perception towards learning literature using PBL approach. The students described their perception as "Excited to use the PBL", "No problem in using PBL", "It is easy", "It is fun and new way of learning boring language", "Not a boring method", "More confident in giving ideas", "No more sleepy times", "Now people can start listening to my ideas", and "Boost my interest in literature as well as to mold me as wholesome students".

For the second question in reflective journal, during the first stage, 45 students reported that they were having problem to immerse themselves in the approach of PBL (early September 2012), while the other ten students did not give their personal response to the questions. However in October 2012, the response from the journals had improved and 55 students reported that they were able to adapt and apply PBL approach in the classroom. The students mentioned about the difficulty to apply the steps in PBL at first. However, along the way, they managed to adapt with the stages in active ladders. The students managed to mingle with their peers very well and work towards the same learning goal. As for interaction with facilitators, students encountered problems during the first stage since the roles of facilitator is not to give everything in terms of direct information to the students. In PBL approach, the responsibility of a facilitator is to guide the students towards solutions. However, along the way, the students managed to survive in the class and adapt themselves with new roles of facilitator. As the semester went on, the students seemed to have adapted in applying the approach in the literature classroom. Four of the students mentioned in the journals that:

\title{
Excerpt3
}

“Well Madam M..I can't lie to myself..at first..i don't favor this approach as I think it is too much for me...I like it if it is only the lecturer who has to give us everything..it makes our life easier...give us the points and we just memorize and answer the question, give us the framework for assignment and we just do it..but what you said make sense...we are being pampered that way..won't survive in our career.we ought to think out of the box...yes, sincerely, this is one of the best method for degree students.. we should be challenged, not being pampered ..."

Excerpt4

"It is interesting Madam M..we are now challenging ourselves to move forward.. all these while, we got "subsidi kerajaan" from other lecturers by giving the notes right away..if they don't give notes..we will piss off, start talking bad at their backs.. all we want to do is memorizing the notes for final exam and get an A..process, collaborative, cooperative learning is of no use..butnow..I am okay with PBL..it teaches me to gel with other people...to defend my points as well as accepting others point of views... with PBL, we explore what are the things in our minds.. and I can see different people think differently..how amazing..I learn a lot from that..could use this in future as well..."

(December $15^{\text {th }}$, 2012) 
"It is interesting Madam M..The best part would be when you instruct us to go to the library in searching for the resources to settle the problem scenario given..We were like..Hello? I hate library..But amazingly, we found many info from the library..From the online journals, books (eventhough not much on literature) and from the net as well...we have to be very good in picking up the best info to be used in the presentation later..Previously, I will take anything from Wikipedia, but now no more..I evaluate first and decide the best..Couldn't believe myself now"

(December15 $5^{\text {th }}$ 2012)

\subsection{The Impacts of Using PBL approach in Promoting Critical Thinking Skills among Students}

\subsubsection{From Students' Reflective and Researcher's Reflective Journals}

For the last question in reflective journal on the question "What has today's class taught you about being a critical thinker in solving the problem scenario given?", most of the students with 53 out of 55 believed that they are now can be categorized under critical thinker. This is due to the process that they had to go through while searching for the solutions to the problem scenarios given. The students also mentioned that at the self-directed learning stage, they were quite confused at first. They felt confused on what to do since in the previous classes, everything is given by the lecturers. Thus, the previous action has limited their abilities to be independent in finding solutions. Therefore, when given triggers, they were quite confused and had no confidence to proceed with the next steps. However, along the way, after third triggers were given, they were comfortable with the stage. Due to self-directed learning stage, they were able to groom their confidence while presenting the information that they had for group reporting. They were also happy if their opinions and solutions were heard by group members. For them, it was not an easy process as they had to do research, read, gather and merge all the authorized resources from books and websites in order to come out with possible solutions. According to Zhang (2009), students engage in collaborative learning through interaction with others, which serves as a catalyst for critical thinking. Due to exposure in using PBL approach, the students managed to choose (knowledge), classify and associate (comprehension), generalize and illustrate (application), compare, criticize and question (analyze) as well as draft and plan (synthesis) the solutions for triggers given. Along the way, the students faced cognitive dissonance among themselves. This was the stage where the students used all the information they had from self-directed learning, and in order to choose the best solutions, the students in a group had to discuss about the triggers, shared their opinions about what they understood regarding the issues, analyze and break down the problems and its solutions, compile and constructs the best alternatives and information to be presented in the class as well as to be prepared with possible answers in the question and answers stage later. However, they managed to adapt with the process as the students realized that they had to work collaboratively in order to provide the solutions for problem scenarios given. Proponents of collaborative learning claim that active exchange of ideas within small groups not only increases interest among students but at the same time promotes critical thinking (Gokhale, 1995).In students' opinions, to be critical thinkers, they had to merge all the information from reading and defend it during group and presentation sessions. In the session, they had to know every answer to every question forwarded by their peers. The students also learnt a lot by comparing and contrasting the way on how the frameworks for every problem scenario was formed and arranged by their classmates. In a way, they also learnt from modelling it through facilitators and classmates from other groups. The students managed to define, explain, demonstrate, analyse, invent, develop and justify their solutions to their classmates in the class. All in all, based on the data collected in the research, it can be concluded that the students had positive improvement in terms of critical thinking skills. Problem-based learning also managed to promote critical thinking skills among students in literature class. Two of the students mentioned in the journals that:

Excerpt 6

"I would like to give simple answer.if previously..we were told of what to do in order to settle the problems by lecturers...we just accept without saying a word..but now..we have group members with special tasks given in order to search for the solutions that might have many alternatives.. we have to discuss...sit together..listen to everybody's opinion....look for the information... meet again to give report on the tasks...then decide which would be the best solutions out of many to be presented in front of you..I think, for the time being, I see that as being a critical thinker... a good thing for us, not just for this subject but for future as well Madam M..”

(December 24 $4^{\text {th }}$,2012)

Excerpt 7

"Yes I am now a critical thinking..i am thinking out of the box...Now me and my friends will list out the plan framework for every trigger that will be presented in front of you..at first it is hard but along the way, we can read your mind madam, what is it that you want from us..we know what is it that you want from every presentation for triggers given..I am more organized now..trying to be better student now" $\quad$ (December 26 ${ }^{\text {th }}, 2012$ 


\subsubsection{From Survey Questionnaire}

For Question Five: "How would you rate your improvement in terms of skills in searching and learning the content knowledge in literature class using PBL approach at the end of the semester?", no student had chosen "Poor" as the answer, one students had chosen "Fair" for their choice and 54 students had chosen "Good" as their best choice for the Question Five forwarded. Therefore, it can be concluded that out of 55 students, majority (54 students) believed that their skills in searching and learning content knowledge in literature class by using PBL approach had improved positively.

For Question Six, "Do you think that PBL approach manage to trigger your critical thinking, especially when you are looking for learning issues and solutions to the problem scenarios given?", 55 students had chosen "Yes" for their answer and none of the students had chosen "No." Therefore, it can be firmly said that all the students in literature class strongly believed that PBL approach managed to trigger their critical thinking, especially when they were looking for learning issues and solutions to the problem scenarios given.

According to the results from questionnaire administered, it could be summarized that the integration of PBL approach in teaching literature are accepted by literature students in the classrooms. It also have positive impacts by affecting student's higher order thinking skills while they were working on the solutions from the triggers given.

3.2.3 Lecturers' Evaluation on Fila Tables, Presentation of the Tables before Final Drama Competition and Students' Response from the Reflection Forms Given

In order to elicit information from the data, the students had to fill in FILA tables given for the purpose of the presentation later. In FILA table, the students have to identify facts from the problem scenarios given. Later, together with other group members; they will have to look for ideas regarding facts known. Moving to the third level, they will have to define learning issues from the problem given. Last but not least, from ladder one in using FILA table, these students will have to suggest action plan to solve the problems.

For ladder two, once FILA table is complete, the students moved to ladder two for the next step. Here at this stage, the students will embark themselves in self-directed learning including reading, watching videos, summarizing unit, searching for additional and supporting learning materials. This is as to make sure that they really understood the trigger given and they will have the best ideas to report to their group members in the next meeting pertaining to the posthole given.

In Ladder three, the students organised group reporting. Head of each group by right had the responsibility towards the groups and had to conduct several meetings and all the group members had to report the results of their self-directed learning to the group and prepare for the presentation. This is the time when critical thinking happened. They searched for the information from many resources, chose only the best to be presented in group meetings. At the end of the day, only the best points that would give solutions will be chosen by group members to be presented to the lecturers.

In ladder 4, the students will have to present the outcomes of their learning. They will have to show and describe the process in searching the solutions to the problems using FILA table as well as what had happened in five ladders. If at this stage, there were few points that the groups missed, the lecturers will facilitate the students until their thinking visible to the students.

Last but not least, the students will have to fill in the reflection form given at the end of the presentation. This was carried out to elicit the data that later could back up the research. From the reflection forms given, it can be seen clearly that the students manage to change their roles from passive to active students. They also can model the learning from each other during the presentation took place. It can be said clearly that PBL approach did give positive impacts to the students in terms of transitioning their critical thinking to higher level.

Based on results of the study, the implementation of PBL approach did contribute positive impacts in teaching literature. This was proved by a number of benefits it offered in facilitating the teaching of literature in the classroom. As educators, we should be aware of both the advantages and disadvantages of PBL approach in order to meet with pedagogical needs of teaching and learning the language. Some advantages of PBL approach in teaching are the improvement of soft skill, self-directed learning, metacognition skills in a way that they are now critical thinkers, more creative in solving problems, manage to use higher order thinking, able to collaborate positively in groups in finding the best solutions, and are able to make their thinking visible to themselves, friends and lecturers. Last but not least, PBL approach promoted positive modeling, enhanced meaningful learning and triggered motivation within the students.

\section{Conclusion}

In conclusion, the implementation of PBL approach in teaching literature proved to give positive impacts in enhancing critical thinking skills to teaching literature. It can be concluded that PBL approach is useful in facilitating teaching and learning process in the Malaysian ESL classroom. The findings of this study are generally supported by studies on PBL in which can prepare the students to be flexible thinkers who can work productively with others to solve problems (Hmelo-Silver, 2004; Kain, 2003). Moreover, the PBL method has been demonstrated to increase different types of problem-solving skills in students, from describing specific processes needed to address a particular problem, to increasing the depth and breadth of solutions (Stepien, Gallagher, \&Workman, 1993). Research also suggests that PBL can help students develop self-directed learning skills (Hmelo-Silver, 2004). The results from the study showed that PBL approach has many positive impacts that are useful for learning the content knowledge in a brand new way, and it 
can be adapted to suit students' learning styles. From the observations made, the majority of the students had positive perception and experience during the whole semester of using the instructional approach in the classroom.

Hopefully, research in the future that will be carried out by other researchers will not only bring meaningful results for the teaching field, but also be able to help educators, academicians, language planners, language instructors and lecturers in their quest to search for the best resolution in the language teaching context, especially in teaching core subject. Finally, educators need to have faith in what they are doing, find ways to apply PBL approach and be creative in order to move away from traditional approaches of instruction on their own terms in their own ways.

\section{References}

Ausubel, D.P., Novak, J.D., \& Hanesian, H. (1978). Educational psychology: A cognitive view (2 ${ }^{\text {nd }}$ ed.). New York: Holt, Rinehart and Winston.

Baden, M. (2000). Problem-based learning in higher education : untold stories. Buckingham England Philadelphia, PA: Society for Research into Higher Education \& Open University Press.

Bransford, J.D., Brown, A.L., \& Cocking, R.R. (Eds.) (2000). How people learn: Brain, mind, experience, and school. Washington, DC: National Academy Press.

Bridges, E.M., \& Hallinger, P. (1998). Problem-based learning in medical and managerial education. In R.Fogarty (Ed.), Problem-based learning: A collection of articles (pp. 3019). Arlington Heights, IL: Skylight.

Brookfield, S.D. (1987). Developing critical thinkers: Challenging adults to explore alternative ways of thinking and acting. San Francisco: Jossey-Bass.

Brush, T., \& Saye, J. (2001). The use of embedded scaffolds with hypermedia-supported student-centered learning. Journal of Educational Multimedia and Hypermedia, 10, 333-356.

Coles, C.R. (1990). Evaluating the effects curricula have on student learning: Toward a more competent theory for medical education. In Z.M. Nooman, H.G. Schmidt, \& E.S. Ezzat (Eds.), Innovation in medical education: An evaluation of its present status (pp. 76-93). New York: Springer.

Coles, M. and Robinson, W. (1991) 'Teaching thinking. What is it? Is it possible?' in M.Coles and W. Robinson, Teaching Thinking, Bristol, Bristol Classical Press, pp. 1-23

Costa, A.L., \& O' Leary, P.W. (1992). The cooperative development of the intellect. In N.Davidson \& T. Worsham (Eds.), Enhancing thinking through cooperative learning (pp. 41-65). New

York: Teachers College Press.

Creswell, J. W. (2007). Educational research: Planning, conducting, and evaluating quantitative and qualitative research. Upper Saddle River, NJ: Prentice Hall.

Davidson, N., \& Worsham, T. (Eds.) (1992).Enhancing thinking through cooperative learning. New York: Teachers College Press.

Desiatova, L. (2009).Using Different Forms of Drama in the EFL Classroom.Humanising Language Teaching, 4. Retrieved from http://www. hltmag.co.uk/aug09/sart07.htm

Ertmer, P.A., \& Glazewski, K.D. (2005). Scaffolding teachers' efforts to implement problem-based learning.International Journal of Learning, Volume 12, Issue 4, pp.319-328. Retrieved from

http://www/http://www.edci.purdue.edu/ertmer/docs/ertmer-lc05.pdf

Facione, P.A. (n.d). Critical thinking: What it is and why it counts. http://www.calpress.com/critical.html

Fincham, A.G., \& Shuler, C.F. (2001). The changing face of dental education: The impact of PBL. Journal of Dental Education, 65, 406-21.

Fleming, M. (2006). Drama and language teaching: the relevance of Wittgenstein's concept of language games. Humanising Language Teaching.4. Retrieved from http://www.hltmag.co.uk/jul06/mart01.htm

Gokhale, A. A. (1995) Collaborative learning enhances critical thinking. Journal of Technology Education, 7(1), 22-30. Retrieved from http://scholar.lib.vt.edu/ejournals/JTE/v7n1/pdf/gokhale.pdf

Hmelo-Silver, C.E. (2004). Problem-based learning: What and how do students learn? Educational Psychology Review, 16, 235-266.

Honore, S. \& Schofield, C.P. (2009). Generation y: Learning and working. Retrieved from

http://www.ashridge.com/Website/Content.nsf/wFARCRED/Generation+Y+Research?opendocument

Hunkins, F.P. (1989). Teaching thinking through effective questioning. Boston: Christopher-Gordon.

Hussain,M.A.,Nafees,M. and Jumani, N.B.(2009). The Second Language Learners' Achievement in Literature through Problem Based Learning Method. Journal of the Scholarship of Teaching and Learning. Vol.

9(3), 87-94. Retrieved from http://josotl.indiana.edu/article/view/2144

Jeffery, B., and Woods, P. (2003). The creative school: A framework for success, quality and effectiveness. New York: Routledge Falmer.

Jones, S. J. (2006). Blogging and ESL writing: A case study of how students responded to the use of weblogs as a pedagogical tool for the writing process approach in a community college ESL writing class. Dissertations \& Theses. Retrieved from ProQuest Digital Dissertations database.(Publication No. 3254430)

Kain, D.L.(2003). Problem-based learning for teachers, Grades 6-12. Boston: Allyn and Bacon.

Kinney, J. (1980) 'Why bother? The importance of critical thinking', in R.E Young, Fostering Critical Thinking, New Directions for Teaching and Learning, San Francisco, Jossey-Bas, pp. 1-10. Kirszner, L. \&Mandell, S. (2007). Literature : reading, reacting, writing. Boston: Thomson/Wadsworth.

Keeley, S. and Shemberg, K. (1995) 'Coping with student resistance to critical thinking', College Teaching, 43(4), 140- 
147

Kuhn, D. (1999) ‘ A developmental model of critical thinking’, Educational Researcher, 28(2), 16-26

Maley, A. \& Duff, A. (2005). Drama techniques : a resource book of communication activities for language teachers. Cambridge New York: Cambridge University Press.

Maudsley, G., \& Strivens, J. (2000). Promoting professional knowledge, experiential learning and critical thinking for medical students. Medical Education, 34, 535-44.

McCombs, B.L., \& Whistler, J.S. (1997).The learner-centered classroom and school. San Francisco: JosseyBass.Newble, D.I., \& Clarke, R.M. (1986). The approaches to learning of students in a traditional and in an innovative problem-based medical school. Medical Education, 19, 267-73.

McKay, J and Kember, D. (1997) 'Spoonfeeding lead to regurgitation: a better diet can result in more digestible learning outcomes', Higher Education Research and Development, 16(1), 55-67

Meyers, C. (1986) Teaching Students to Think Critically, San Francisco, Jossey-Bass Normala Othman and Mohamed Ismail Ahamad Shah (2013), Problem-based learning in the English classroom. English Language Teaching, Vol. 6, No 3, 2013. Pp. 125-127. http://dx.doi.org/10.5539/elt.v6n3p125 Pascarella, E.T., \& Terenzini, P.T. (1991).How college affects students: Findings and insight from twenty years of research. San Francisco: Jossey-Bass.

Rashid, A. R., Rahman, M. F. A., \&Rahman, S. B. A. (2016). Teachers' engagement in social support process on a networking site. Journal of Nusantara Studies, 1(1), 34-45.

Rhem, J. (1998). Problem-based learning: An introduction. National Teaching and Learning Forum, 8, 1-4.

Davies, M. \& Barnett, R. (2015). The Palgrave handbook of critical thinking in higher education. New York, NY: Palgrave Macmillan.

Sadker, D., Sadker, M. \& Zittleman, K. (2008). Teachers, schools, and society (8th ed.) Boston: McGraw-Hill.

Schunk, D.H. (2000). Learning theories: An educational perspective ( $3^{\text {rd }}$ ed.). Upper Saddle River, NJ: Merrill.

Senge, P.M. (1990). The fifth discipline: The art and practice of the learning organization. New York: Doubleday.

Siti Norliana Ghazali (2008). Learner Background and Their Attitudes towards Studying Literature. Malaysian Journal of ELT Research, 4, 1-17.

Stinson, J.E., \& Milter, R.G. (1996). Problem-based learning in business education: Curriculum design and implementation issues. In L. Wilkerson \& W.H. Gijselaers (Eds.), Bringing problem-based learning to higher education: Theory and practice (pp. 33-42). New directions for teaching and learning, No. 68. San Francisco: JosseyBass.

Svinicki, M.D. (1999). Teaching and learning on the edge of the millennium: Building on what we have learned. New directions for teaching and learning, No. 80. San Francisco: Jossey-Bass.

Tan, O.S. (2009). Problem-based learning and creativity. Singapore: Cengage Learning Asia.

Tan, O.S. (2004). Cognition, Metacognition, and Problem-based Learning. In Tan, O.S. (Ed.), Enhancing thinking through problem-based learning approaches: International perspectives (pp. 1-16). Singapore:Thomson Learning.

Tan, O.S. (2003). Problem-based learning innovation. Singapore: Thomson.

Vernon, D.T.A., \& Blake, R.L. (1993). Does problem-based learning work? A meta-analysis of evaluative research. Academic Medicine, 68, 550-63.

Weissinger, P.A. (2003). Critical thinking skills of first-year dental students enrolled in a hybrid curriculum with a problem-based learning component. Doctoral dissertation, Indiana University, Bloomington.

Zhang, D. (2009). The application of blog in English writing.Journal of CambridgeStudies, 4(1), 64-72. Retrieved from http://journal.acs_cam.org.uk/data/archieve/2009/200901_article8.pdf

Zyoud, M. (n.d). Using Drama Activities and Techniques to Foster Teaching English as a Foreign Language: a

Theoretical Perspective. Retrieved from

http://www.qou.edu/english/conferences/firstNationalConference/pdfFiles/muntherZyoud.pdf 